\title{
PANGGILAN QURAN KEPADA UMAT MANUSIA
}

\begin{abstract}
Abdul Haris
Abstrak

Di dalam quran menjelaskan kualitas serta nilai manusia dengan menggunakan empat jenis istilah yang satu sama lain saling berkaitan yaitu al-insaan, an-naas, al-basyar, dan bani adam. Manusia yang dijuluki sebagai al-insaan karena dia sering menjadi pelupa sehingga diperlukan teguran dan peringatan. Kemudian an-naas (terambil dari kata annaws yang berarti gerak, dan ada juga yang berpendapat bahwa ia berasal dari kata unaas yang berarti nampak) digunakan untuk menunjukkan sekelompok manusia baik dalam arti jenis manusia atau sekelompok tertentu dari manusia. Selanjutnya disebut al-basyar, karena dia cenderung perasa dan emosional sehingga perlu disabarkan dan didamaikan. Manusia disebut sebagai banii Aadam karena dia menunjukkan pada asalusulyang bermula dari nabi Adam as sehingga dia bisa tahu dan sadar akan jati dirinya. Misalnya, dari mana dia berasal, untuk apa dia hidup, dan ke mana ia akan kembali. Penggunaan istilah banii Aadam menunjukkan bahwa manusia bukanlah merupakan hasil evolusi dari makhluk anthropus (sejenis kera). Hal ini diperkuat lagi dengan panggilan kepada Adam dalam quran oleh Allah dengan huruf nidaa (Yaa Adam)
\end{abstract}

Kata Kunci: Panggilan dan Alquran

\section{A. Pendahuluan}

Alquran memandang manusia sebagaimana fitrahnya yang suci dan mulia, bukan sebagai manusia yang kotor dan penuh dosa. ${ }^{1}$ Peristiwa yang menimpa Nabi Adam sebagai cikal bakal manusia,yang melakukan dosa dengan melanggar larangan Tuhan, mengakibatkan Adam dan istrinya diturunkan dari sorga, tidak bisa dijadikan argumen bahwa manusia pada hakikatnya adalah pembawa dosa turunan. Quran justru memuliakan manusia sebagai makhluk surgawi yang sedang dalam perjalanan menuju suatu kehidupan spiritual yang suci dan abadi di negeri akhirat, meski dia harus melewati rintangan dan cobaan dengan beban dosa saat melakukan kesalahan di dalam hidupnya di dunia ini. Bahkan manusia diisyaratkan sebagai makhluk spiritual yang sifat aslinya adalah berpembawaan baik (positif, haniif). Karena itu, kualitas, hakikat, fitrah, kesejatian manusia adalah baik, benar, dan

${ }^{1}$ Rif'at Syauqi Nawawi, Konsep Manusia Menurut al-Qur'an, Makalah Disampaikan Pada Simposium Psikologi Islami, Pada Sabtu, tanggal, 14 Desember 1996, (Universitas Padjadjaran, Bandung, 1996), h. 78. 
indah. Tidak ada makhluk di dunia ini yang memiliki kualitas dan kesejatian semulia itu. Sungguhpun demikian, harus diakui bahwa kualitas dan hakikat baik benar dan indah itu selalu mengisyaratkan dilema-dilema dalam proses pencapaiannya. Pada tulisan ini akan membahas panggilan quran kepada umat manusia.

\section{B. Ayat Pembahasan}

\section{Al Insan (Termasuk Golongan Ayat Makiyyah)}

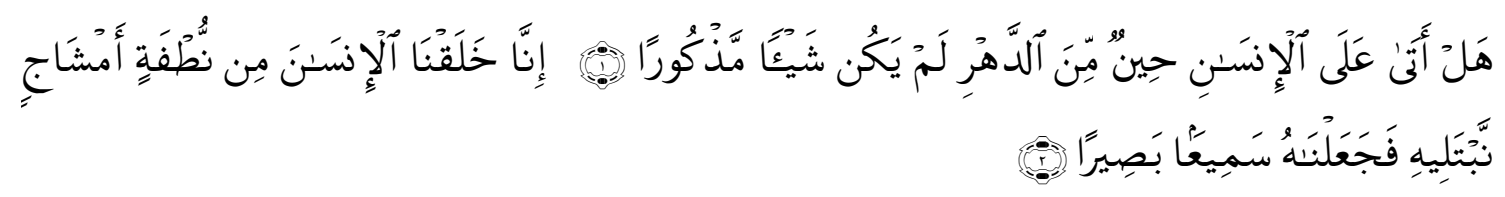

Artinya: Bukankah telah datang kepada manusia satu waktu dari masa, yang ketika itu ia belum merupakan sesuatu yang dapat disebut?, "Sungguh Kami telah menciptakan manusia dari setetes mani yang bercampur untuk Kami uji. Karena itu, Kami jadikan ia mendengar dan melihat" (QS. Al Insan : 1-2)

\section{An Naas (Pembahasan Ayatnya Tergolong Ayat Makiyyah)}

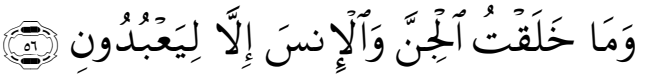

Artinya : "Dan aku tidak menciptakan jin dan manusia melainkan supaya mereka mengabdi kepada-Ku" (Adz-Dzaariyat : 56)

\section{Al Basyar (Pembahasan Ayatnya Tergolong Makiyyah)}

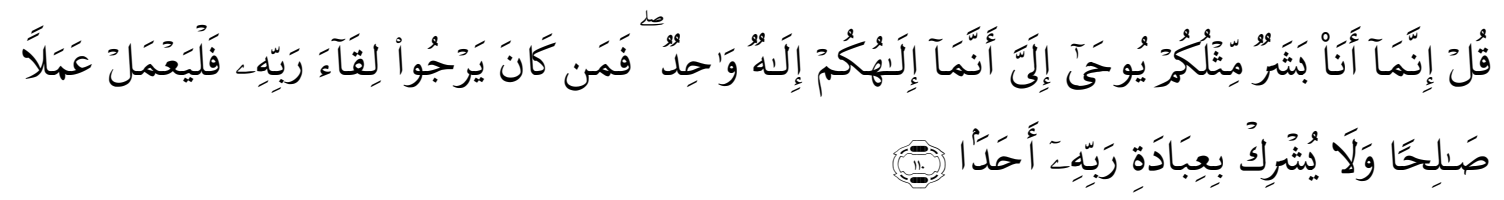

Artinya: Katakanlah: Sesungguhnya Aku Ini manusia biasa seperti kamu, yang diwahyukan kepadaku: "Bahwa Sesungguhnya Tuhan kamu itu adalah Tuhan yang Esa". barangsiapa mengharap perjumpaan dengan Tuhannya, Maka hendaklah ia mengerjakan amal yang saleh dan janganlah ia mempersekutukan seorangpun dalam beribadat kepada Tuhannya" (QS. Al Kahfi : 110).

\section{Bani Adam (Tergolong ayat Madaniyah)}

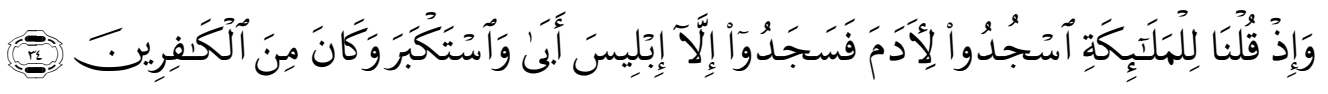


Artinya: Dan (ingatlah) ketika Kami berfirman kepada para malaikat: 'Sujudlah kamu kepada Adam, 'maka sujudlah mereka kecuali Iblis; ia enggan dan takabur dan adalah ia termasuk golongan orang-orang yang kafir. (QS. Al Baqarah : 34)

\section{Pembahasan}

\section{Al Insan}

Kata Insan yang berasal dari kata al-Uns dinyatakan dalam quran sebanyak 65 kali dan tersebar dalam 43 surat $^{2}$. Insan dapat diartikan secara etimologis adalah harmonis, lemah lembut, tampak atau pelupa. Kata insan digunakan dalam quran untuk menunjuk kepada manusia dengan seluruh totalitasnya, jiwa dan raganya ${ }^{3}$. Kata ini dinyatakan dalam quran sebanyak $73 \mathrm{kali}^{4}$.

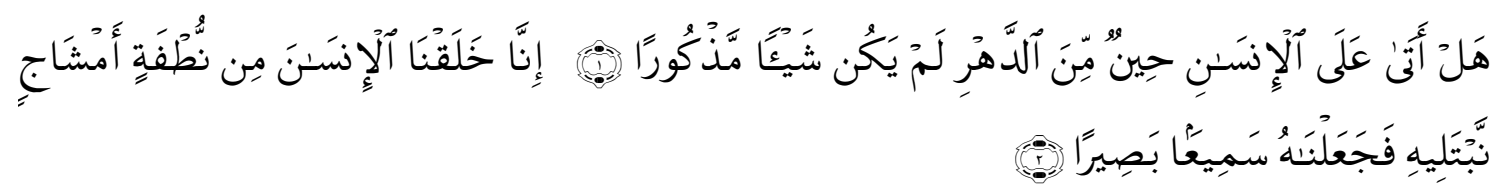

Artinya : Bukankah telah datang kepada manusia satu waktu dari masa, yang ketika itu ia belum merupakan sesuatu yang dapat disebut?, "Sungguh Kami telah menciptakan manusia dari setetes mani yang bercampur untuk Kami uji. Karena itu, Kami jadikan ia mendengar dan melihat" (QS. Al Insan : 1-2)

Ayat ini berkaitan dengan ayat setelahnya yaitu Quran surah al Insan ayat 3 mengenai kejadian manusia.

\section{Tafsir}

Jika dilihat dari aspek bahasa, kata ÅäÓÇä (Insân) menurut Ibn Mandzhur diambil dari tigaakarkata, yaitu; ÃóäóÓó (anasa), ÃóäøóÓó (annasa) sertaäóÓöóó (nasiya).KataÃóäóÓóó (anasa)

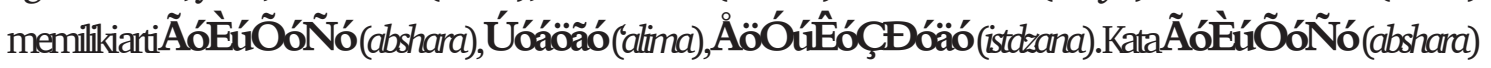
berarti melihat, bernalar, berpikir. Dengannya manusia dapat mengambil pelajaran dari apa yang mereka lihat. Kata Úóáöãó ('alima) berarti mengetahui atau berilmu. Dengan ilmunya manusia dapat membedakan suatu perkara apakah itu benar atau salah. Sedangkan kata ÅöÓúÊÉÇĐóäó (istdzana) memilikiartimemintaizin. Manusia merupakan makhlukyang beradab yang kadang meminta izin ketika akan melakukan sesuatu atau menggunakan sesuatu

${ }^{2}$ Muhammad Fu'ad Abdul Baqi, Al-Mu'jam al-Mufahras li alfadz al-Qur'an al-Karim, (T.kp.: Darul Fikri, 1992), h. 119-120.

${ }^{3}$ Quraish Shihab, Wawasan al-Qur'an; Tafsir Maudhu'i atas Pelbagai Persoalan Umat, (Bandung: Mizan, 1996), h. 280.

${ }^{4}$ Samsul Nizar, M.A., Filsafat Pendidikan Islam, Pendekatan Historis, Teoritis dan Praktis, (Jakarta: Ciputat Pers, 2002), h. 5. 
yang bukan miliknya. Berdasarkan pembedahan kata ini, al-Insân dapat diartikan sebagai makhluk yang mempunyai kemampuan untuk menalar, makhluk yang berilmu serta makhluk yang beradab.

Berdasarkan pemaparan di atas, dapat di simpulkan bahwa al-Insân dapat diartikan sebagai makhluk yang memiliki kemampuan menalar dan berpikir yang dengannya manusia dapat mengambil pelajaran dari apa yang mereka lihat sehingga ia dapat maju dan berkembang. Ia merupakan makhluk yang berilmu, sehingga dengan ilmunya ia dapat membedakan suatu perkara apakah itu benar atau salah. Ia merupakan makhluk yang pada hakikatnya memiliki adab sehingga ia tidak suka merampas dengan mengambil hak orang lain tanpa meminta izin. Ia merupakan makhluk yang pada hakikatnya ramah dalam pergaulan serta bersahabat dengan lingkungan, namun terkadang ia lupa (khilaf) sehingga dengan mudah dipengaruhi Syaithan untuk melaju ke jalan yang salah.

Menurut Jalaludin Rahmat memberi penjabaran al-insan secara luas pada tiga kategori. Pertama, al-insan dihubungkan dengan keistimewaan manusia sebagai khalifah dan pemikul amanah. Kedua, al-insan dikaitkan dengan predisposisinegatif yang inherendan laten pada diri manusia. Ketiga, al- insan disebut dalam hubungannya dengan proses penciptaan manusia. Kecuali kategori ketiga, semua konteks al-insan menunjuk pada sifat-sifat psikologis atau spiritual. Kategori pertama dapat difahami melalui tiga penjelasan sebagai berikut:

a. Manusia dipandang sebagai makhluk unggulan atau puncak penciptaan Tuhan. Keunggulannya terletak pada wujud kejadiannya sebagai makhluk yang diciptakan dengan sebaik-baik penciptaan. Manusia juga disebut sebagai makhluk yang dipilih Tuhan untuk mengemban tugas kekhalifahan di muka bumi.

b. Manusia adalah satu-satunya makhluk yang dipercaya Tuhan untuk mengemban amanah, suatu beban sekaligus tanggung jawabnya sebagai makhluk yang dipercaya untuk mengelola bumi. Menurut Fazlurrahman, amanah yang dimaksud terkait dengan fungsi kreatif manusia untuk menemukan hukum alam, menguasainya dalam bahasa al-Quran (mengetahuinama-nama semuabenda), dan kemudian menggunakannya dengan insiatif moral untuk menciptakan tatanan dunia yang lebih baik. Sedangkan menurut Thabathaba'I, Amanah yang dimakdus Sebagai predisposisipositif (isti'dad) untuk beriman dan mentaati Allah. Dengan kata lain manusia didisposisikan sebagai pemikul al-wilayah al-Ilahiyah.

c. Merupakan konsekuensi dari tugas berat sebagai khalifah dan pemikul amanah, manusia dibekali dengan akal kreatif yang melahirkan nalar kreatif sehingga manusia memiliki kemampuan untuk mengembangkan ilmu pengetahuan. Karena itu berkali-kali kata al-insan dihubungkan dengan perintah melakukan nadzar (pengamatan, perenungan, pemikiran, analisa) dalam rangka menunjukkan kualitas pemikiran rasional dan kesadaran khusus yang dimilikinya.

d. Dalam mengabdi kepada Allah manusia (al-insan) sangat dipengaruhi oleh lingkungan 
dan kondisi psikologisnya. Jika ditimpa musibah ia selalu menyebut nama Allah. Sebaliknya jika mendapat keberuntungan dan kesuksesan hidup cenderung sombong, takabbur, dan musyrik.

Kata al-insan juga digunakan dalam al-Qur'an untuk menunjukkan proses kejadian manusia sesudah dan kejadiannya mengalami proses yang bertahap secara dinamis dan sempurna di dalam di dalam rahim. ${ }^{5}$ Sebagaimana dalam al-qur'an dalam surah al-Nahl ayat 78, yaitu: "dan Allah mengeluarkan kamu dari perut ibumu dalam Keadaan tidak mengetahui sesuatupun, dan Dia memberi kamu pendengaran, penglihatan dan hati, agar kamu bersyukur". Penggunaan kata al-insan dalam ayat ini mengandung dua makna yaitu: Pertama,makna proses biologis, yaitu berasal dari saripati tanah melalui makanan yang dimakan manusia sampai pada proses pembuahan. Kedua, makna proses psikologis (pendekatan spiritual), yaitu proses ditiupkan ruh-Nya pada diri manusia, berikut berbagai potensi yang dianugerahkan Allah kepada manusia.

Makna pertama mengisyaratkan bahwa manusia pada dasarnya merupakan dinamis yang berproses dan tidak lepas dari pengaruh alam serta kebutuhan yang menyangkut dengannya. Keduanya saling mempengaruhi antara satu dengan yang lain. Sedangkan makna kedua mengisyaratkan bahwa, ketika manusia tidak bisa melepaskan diri dari kebutuhan materi dan berupaya untuk memenuhinya, manusia juga dituntut untuk sadar dan tidak melupakan tujuan akhirnya, yaitu kebutuhan immateri (spiritual). Untuk itu manusia diperintahkan untuk senantiasa mengarahkan seluruh aspek amaliahnya pada realitas ketundukan pada Allah, tanpa batas, tanpa cacat, dan tanpa akhir. Sikap yang demikian akan mendorong dan menjadikannya untuk cenderung berbuat kebaikan dan ketundukan pada ajaran Tuhannya.

Ada dua bentuk peranan dan tanggung jawab manusia di permukaan bumi yaitu:

a. Peran dan Tanggungjawab Manusia sebagai Hamba Allah dan Makhuk Sosial.

b. Peran dan Tanggungjawab Manusia sebagai Khalifah fil Ardl

\section{An Naas}

An-Naas dalam al-Qur'an disebutkan sebanyak 241 kali dan tersebar dalam 55 surat. Dalam quran keterangan yang jelas menunjukkan pada jenis keturunan nabi Adam as. kata an-Nas menunjuk manusia sebagai makhluk sosial dan kebanyakan digambarkan sebagai kelompok manusia tertentu yang sering melakukan.

\section{Tafsir}

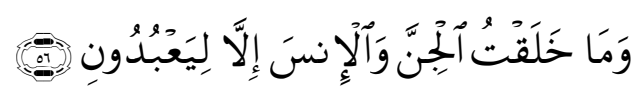

Artinya: "Dan aku tidak menciptakanjin dan manusia melainkan supaya merekamengabdi kepada-Ku”" (Adz-Dzaariyat : 56)

${ }^{5}$ M.Quraish Shihab, Wawasan al Qur'an, Cetakan VII, (Bandung: Penerbit Mizan, 1998), h. 284. 
Ayat ini berkaitan dengan ayat sebelumnya yaitu ayat 55 mengenai peringatan bagi orang yang beriman agar selalu patuh dan taat kepada Allah sebagai pencipta.

KataÃóäøóÓó (annasa) berartijinak, ramah. Manusia merupakan makhlukyang bersahabat dan ramah pergaulan. Sedangkan kata äóÓöóó (nasiya) berarti lupa. Manusia merupakan makhluk yang memiliki sifat lupa. Quraish Shihab mengartikan kata Insân sebagai seorang yang harmonis, tampak, lemah lembut atau pelupa. Dalam bahasa inggris al-Insân disebut sebagai human (manusia).

\section{Asbabun Nuzul}

Ketika para malaikat mengetahui bahwa Allah SWT akan menciptakan khalifah di muka bumi. Allah SWT menyampaikan perintah-Nyakepadamereka secara terperinci. Diamemberitahukan bahwa Dia akan menciptakan manusia dari tanah. Maka ketika Dia menyempurnakannya dan meniupkan roh di dalamnya, para malaikat harus bersujud kepadanya. Yang harus dipahami bahwa sujud tersebut adalah sujud penghormatan, bukan sujud ibadah, karena sujud ibadah hanya diperuntukkan kepada Allah SWT.

\section{Makna Mufrodat Dan Kandungan Ayat :}

Didahulukannya penyebutan kata (Çálä) Jin dari kata (ÇáÅäÓ) manusia karena jin memang lebih dahulu diciptakan Allah dari pada manusia. Huruf (á) pada kata (áíu̇i̇̇aä) bukan berarti agar supaya mereka beribadah atau agar Allah disembah, sedangankan Menurut Muhammad Quraish Shihab dalam tafsirnya ayat di atas adalah sebagai berikut: "Dan Aku tidak menciptakan jin dan manusia untuk satu manfaat yang kembali pada diri-Ku. Aku tidak menciptakan mereka melainkan agar tujuan atau kesudahan aktivitas meraka adalah beribadah kepada-Ku.

Ayat di atas menggunakan bentuk persona pertama (Aku), karena memang penekannya adalah beribadah kepada-Nya semata-mata, maka redaksi yang digunakan berbentuk tunggal dan tertuju kepada-Nya semata-mata tanpa memberi kesan adanya keterlibatan selain Allah swt, huruf lam disini sama dengan huruf lam dalam firman Allah SWT:

"Maka dipungutlah ia oleh keluarga Fir'aun yang akibatnya Dia menjadi musuh dan Kesedihan bagi mereka. Sesungguhnya Fir'aun dan Haman beserta tentaranya adalah orang-orang yang bersalah."

Bila huruf lam pada liyakuna dipahami dalam arti agar supaya, maka di atas seperti: maka dipungutlah dia oleh keluarga fir'aun agar supaya dia Musa yang dipungut itu menjadi musuh dengan kesedihan bagi mereka. Thabathaba'i memahami huruf lam pada ayat yang ditafsirkan dalam arti agar supaya, yakni tujuan penciptaan manusia dan jin adalah untuk beribadah. Ulama ini menulis bahwa tujuan apapun bentuknya adalah sesuatu yang digunakan oleh yang bertujuan untuk menyempurnakan apa yang belum sempurna baginya atau 
menanggulangi kebutuhan/kekurangannya. Tentu saja hal ini mustahil bagi Allah SWT, karena dia tidak memiliki kebutuhan. ${ }^{6}$ Dengan demikian tidak ada lagi baginya yang perlu disempurnakan. Namun disisi lain, suatu perbuatan yang tidak memiliki tujuan adalah perbuatan sia-sia yang perlu dihindari.

Mengapa, hai Muhammad, kamu diperintahkan untuk memperingatkan umat manusia? Kamu diperintahkan untuk memperingatkan bahwa jin dan manusia tidak diciptakan kecuali untuk beribadat kepada-Ku. Jin dan manusia dijadikan oleh Allah untuk beribadah kepadaNya. Tegasnya, Allah menjadikan kedua makhluk itu sebagai makhluk-makhluk yang mau beribadah, diberi akal dan panca indera yang mendorong mereka menyembah Allah, untuk beribadahlah tujuan mereka diciptakan. Dengan demikian, ibadah yang dimaksud disini lebih luas jangkauannya daripada ibadah dalam bentuk ritual. Tugas kekahlifahan termasuk dalam makna ibadah dan dengan demikian hakekat ibadah mencakup dua hal pokok. Pertama: kemantapan makna penghambaan diri kepada Allah dalam hati setiap insan. Kedua: mengarah kepada Allah dengan setiap gerak pada nurani, pada setiap anggota badan dan setiap gerak dalam hidup

\section{Al Basyar}

Basyar dinyatakan dalam al-Qur'an sebanyak 36 kali dan tersebar dalam 26 surat. Secara etimologi Basyar berarti kulit kepala, wajah, atau tubuh yang menjadi tempat tumbuhnya rambut. Penamaan ini menunjukkan makna bahwa secara biologis yang mendominasi manusia adalah pada kulitnya. Pada aspek ini terlihat perbedaan umum biologis manusia dengan hewan yang lebih didominasi oleh bulu atau rambut. Makna etimologis dapat dipahami bahwa manusia merupakan makhluk yang memiliki segala sifat kemanusiaan dan keterbatasan, seperti makan, minum kebahagiaan dan sebagainya.

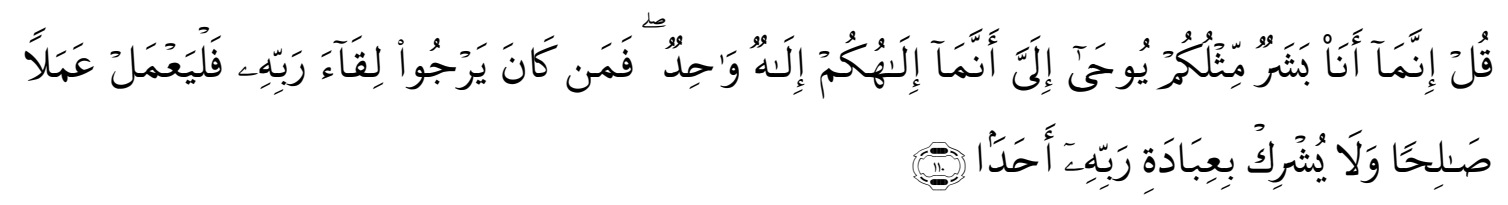

Artinya: Katakanlah: SesungguhnyaAku Ini manusia biasa sepertikamu, yang diwahyukan kepadaku: "BahwaSesungguhnyaTtuhan kamu itu adalah Tuhan yangEsa". barangsiapamengharap perjumpaandenganTuhannya, Maka hendaklahia mengerjakanamal yang salehdan janganlah ia mempersekutukanseorangpundalam beribadatkepada Tuhannya" (QS. Al Kahfi : 110).

Ayat ini berkaitan dengan ayat sebelumnya menceritakan tentang nikmat Allah yang begitu luas kepada mahluknya, sehingga manusia dan mahluk lainnya pantas lah bersyukur kepada Allah. Sampai sejauh ini tidak belum di temukan asbabun nuzul ayat ini.

${ }^{6}$ Syaikh Imam Al Qurthubi, Tafsir Al Qurthubi, (Jakarta:Pustaka Azzam, 2009), h. 293-294. 


\section{Tafsir}

Kata al-basyar dipakai untuk menyebut semua makhluk manusia baik laki-laki maupun perempuan, satu maupun banyak. Kata basyar adalah jamak dari kata basyarah yang berarti permukaan kulit muka, wajah dan tubuh yang menjadi tempat tumbuhnya rambut. Ibn Barjah mengartikannya sebagai kulit luar. ${ }^{7}$ al-Laits mengartikannya sebagai permukaan kulit pada wajah dan tubuh manusia, karena itu kata mubasyarah diartikan mulamasah yang berarti persentuhan antara kulit laki-laki dan kulit perempuan, disamping itu kata mubasyarah diartikan sebagai al-wath' atau al-jima' yang berarti persetubuha.

Pemakaian kata basyar di beberapa tempat dalam Alquran memberikan pengertian bahwa yang dimaksud adalah anak adam yang biasa makan dan berjalan di pasar-pasar, dan di dalam pasar itu mereka saling bertemu atas dasar persamaan. Jadi basyar untuk menyebut pada semua makhluk, mempunyai pengertian adanya persamaan umum yang selalu menjadi ciri pokok. Ciri pokok itu adalah kenyataan lahiriah yang menempati ruang dan waktu, serta terikat oleh hukum-hukum alamiahnya.

Manusia dalam pengertian basyar mempunyai bangunan tubuh yang sama, makan dan minum dari bahan yang sama yang ada dalam alam ini, dan oleh bertambahnya usia, kondisi tubuhnya akan menurun, menjadi tua dan akhirnya ajal pun menjemputnya. Oleh karena itu, manusia dalam pengertian basyar tergantung sepenuhnya kepada alam, pertumbuhan dan perkembangan fisiknya tergantung pada apa yang dimakan dan diminumnya.Dengan demikian, pemakaian basyar untuk merujuk dimensi alamiahnya yang menjadi ciri pokok manusia pada umumnya, makan, minum dan meninggal dunia. ${ }^{8}$

Dengan memahami konsep manusia dari sudut pandang Penciptanya, diharapkan dapat diambil manfaat yaitu munculnya kesadaran terhadap kebenaran firman-firman Tuhan, yang pada gilirannya membentuk pandangan teosentris. Dalam Alquran, kata basyar (tanpa menggunakan alif-lam) sebanyak 31 kali, al-basyar (dengan menggunakan aliflam) sebanyak 5 kali dan basyarain (tanpa alif-lam dalam bentuk dual) sebanyak 1 kali (al-Hasani, t.t.: 52-53). Dari semua ayat tersebut, khususnya basyar dan al-basyar dapat diklasifikasikan menjadi 6 bagian yaitu:

\section{a. Menggambarkan dimensi fisik manusia}

Ada satu ayat yang menyebutkan basyar dalam pengertian kulit manusia, yaitu (Neraka Saqar) akan membakar kulit manusia/lawwahah li al-basyar (lihat Alquran Surat 74: 27-29).

\section{b. Menyatakan Seorang Nabi adalah Basyar}

Ada 23 ayat yang menyatakan bahwa kata basyar dipakai oleh Alquran yang berhubungan

${ }^{7}$ Hasan Langgulung, Manusia Dan Pendidikan,(Jakarta: Pustaka al-Husna, 1984)., h. 107

${ }^{8}$ M. Ali Usman, Manusia Menurut Islam, (Bandung: Mawar, 1970), h. 49. 
dengan dengan Nabi dan kenabian, dan 12 diantaranya menyatakan bahwa seorang nabi adalah basyar, yaitu secara lahiriah mempunyai ciri yang sama yaitu makan dan minum dari bahan yang sama. Antara lain dinyatakan, bahwa para pemuka orang-orang yang kafir dan mendustakan akan menemui hari akhirat: Orang ini tidak lain hanyalah manusia seperti kamu/basyar mitslukum Lihat Alquran Surat 23: 33-34. Lihat juga 14: 10-11, 18: 110, 21: 3, 23: 24, 26 : 154 \& 186, 36: 15, 41: 6 dan 11: 27. Basyar mitslukum di atas ditafsirkan oleh al-Naisaburi sebagai Adami atau anak keturunan Adam yang tidak punya kelebihan apapun atas anak Adam (manusia) lainnya. Namun ayat ini jelas hanyalah klaim orang-orang kafir.

\section{c. Menyatakan tentang kenabian}

Ayat yang menyatakan kata basyar dipakai oleh Alquran dalam kaitannya dengan kenabian sebanyak 11 buah, antara lain: Tidak wajar bagi seorang manusia (basyar) yang Allah berikan kepadanya al-Kitab, hikmah dan kenabian, lalu ia berkata kepada manusia: "Hendaklah kamu menjadi penyembah-penyembahku bukan penyembah Allah" (Alquran Surat 3: 79. Lihat juga 6: 91, 42: 51, 74: 31, 12: 31, 17: 93-94, 23: 34, dan 54: 24). alThabathaba'i (1972: 275) menafsirkan, tidak patut bagi seorang manusia (dalam hal ini Nabi) yang diberikan Tuhan karunia yang berlimpah, lalu memproklamirkan dirinya agar disembah, hanya karena ia diberikan al-Kitab, hikmah dan kenabian.

\section{d. Menunjukkan Persentuhan Laki-laki dan Perempuan}

Ada 2 ayat yang menyebutkan kata basyar dalam kaitannya dengan per-sentuhan antara laki-laki dan perempuan. Maryam berkata: "Bagaimana mungkin akan ada bagiku seorang anak laki-laki, sedang tidak pernah seorang manusia (wa lam yamsasni basyar) pun menyentuhku, dan akan bukan pula seorang pezina" (lihat Alquran Surat 19: 20, lihat juga 3: 47) Lam yamsasni basyar, ditafsirkan oleh al-Naisaburi dengan tidak pernah seorang suami pun mendekatiku, wa lam aku baghiyya, bukan pula seorang lacur (mendekatiku), dan aku sendiri bukan seorang pezina. Seorang anak tidak mungkin ada kecuali dari (hubungan) suami isteri atau berzina?.

\section{e. Menggambarkan Manusia pada umumnya}

Alquran yang menggunakan kata basyar dalam pengertian manusia pada umumnya sebanyak 5 ayat, antara lain: "Ini tidak lain hanyalah perkataan manusia" (In hadza illa qawl al-basyar) (Alquran Surat 74: 25, lihat juga 19: 17, 74: 36, 19: 26).

Kebanyakan mufassir tidak mengomentari lagi ayat ini karena sudah sangat jelas kandungannya, namun al-Sayuthi dan al-Mahalli sedikit memberikan penjelasan bahwa ini merupakan rekaman perkataan orang-orang kafir dimana mereka mengatakan sesungguhnya

${ }^{9}$ Ibid., h. 109 
Alquran itu hanya ajaran yang disampaikan oleh manusia biasa menambahkan, bahwa orang-orang kafir mengatakan Alquran itu hanya dikutip dari perkataan orang lain (manusia biasa) saja, bukan kalam Allah sebagaimana dakwaannya (Muhammad).

\section{f. Menyatakan proses penciptaan dari tanah}

Yang menyatakan arti basyar sebagai proses penciptaan manusia dari tanah ada 4 ayat, antara lain: Di antara tanda-tanda kekuasan-Nya ialah Dia menciptakan kamu dari tanah, kemudian tiba-tiba kamu (menjadi) manusia yang berkembang biak/basyar tantasyirun (Alquran Surat 30: 29. Lihat juga 38: 71, dan 15: 28).Dia menciptakan kamu dari tanah, dimaksud adalah basyar (manusia), kemudian menjadi manusia yang terdiri dari daging dan darah yaitu keturunannya yang tersebar di permukaan bumi (al-Naisaburi, 1994: 431) Menunjukkan manusia akan menemui kematian

Alquran yang menerangkan kata basyar dalam pengertian semua manusia akan menemui kematian hanya 1 ayat, yaitu: Kami tidak menjadikan hidup abadi bagi seorang manusia pun sebelum kamu (wa ma ja'alna li basyar min qablik al-khuld), maka jikalau kamu (Muhammad) mati, apakah mereka akan kekal? Tiap-tiap yang berjiwa akan merasakan mati ... (Alquran Surat 21: 34-35)

\section{Bani Adam}

Bani Adam di sebutkan dalam al-Qur'an sebanyak 9 kali. Di antaranya pada surat Yasin ayat 60. Adam di dalam al-Qur'an mempunyai pengertian manusia dengan keturunannya yang mengandung pengertian basyar, insan dan an-Nas. Kata Bani Adam lebih ditekankan pada aspek amaliah manusia, sekaligus pemberi arah ke mana dan dalam bentuk apa aktivitas itu dilakukan.

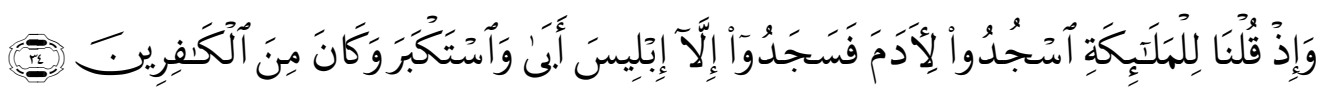

Artinya: Dan (ingatlah) ketika Kami berfirman kepada para malaikat: 'Sujudlah kamu kepada Adam, 'maka sujudlah mereka kecuali Iblis; ia enggan dan takabur dan adalah ia termasuk golongan orang-orang yang kafir. (QS. Al Baqarah : 34)

Ayat ini berkaitan dengan ayat sebelumnya yaitu ayat 30, 31,32 dan 33 mengenai penciptaan adam di dunia sebagai seorang khalifah. Mengenai asbabun nuzul ayat penulis belum menemukannya.

\section{Tafsir}

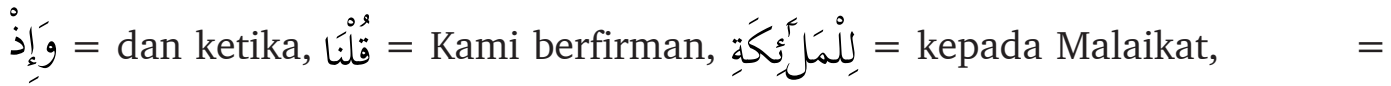

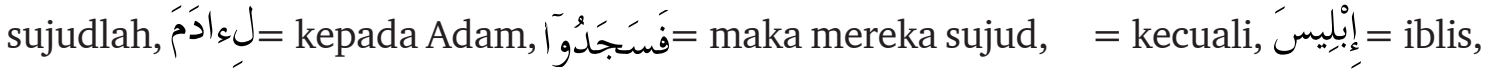




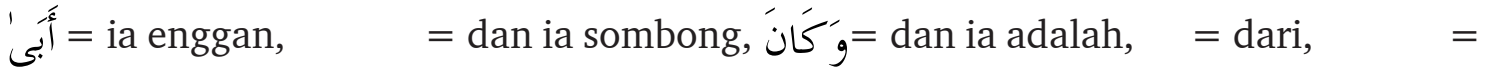
orang-orang kafir.

Sujud ini dilakukan karena penciptaan manusia, bukan karena pengangkatannya sebagai khalifah. Karena persoalan khilafah serta pengujian terhadap para Malaikat terjadi setelah tahap ini. Pada dasarnya, jika perintah sujud dikeluarkan setelah kejelasan kedudukan khilafah yang dicapai oleh Adam as, maka sujudnya para Malaikat itu tak akan sedemikian bernilai. Karena sudah bukan lagi berdasarkan pada ta'abbud dan penyerahan diri sepenuhnya kepada perintah ilahi, namun sujud itu dilakukan karena kedudukan Adam.

Sementara itu, Iblis, yang menurut ayat 50 surat al-Kahfi termasuk dari golongan Jin yang mencapai kedudukan setingkat dengan para malaikat berkat ibadahnya yang sangat tinggi, tidak bersedia melaksanakan perintah Ilahi itu. Dengan menyombongkan diri ia menyangka bahwa dari segi ciptaan ia lebih tinggi dari pada Adam. Menurutnya, Adamlah yang seharusnya bersujud kepadanya, bukan ia yang sujud terhadap Adam. Kemaksiatan dan dosa Iblis bukan hanya di dalam perbuatan; tetapi dari segi keyakinan Iblis juga telah menunjukkan kemaksiatannya. Karena ia menyakini bahwa perintah Allah itu tidak adil dan bijaksana.

Dengan demikian maka Iblis telah kafir, tak beragama dan melepaskan imannya. Sujudnya para malaikat kepada Adam bukan berarti menyembah Adam. Sebab menyembah selain Allah tidak diperbolehkan. Mereka bersujud kepada Adam atas dasar perintah Ilahi sebagai penghormatan, yang pada hakikatnya bersujud kepada Allah, namun karena penciptaan wujud mulia ini yang bernama manusia.

Dari ayat tadi terdapat enam poin pelajaran yang dapat dipetik:

1. Hakikat ibadah adalah manusia melakukan perbuatan karena perintah Allah, bukannya ia memilih dan mengamalkan perintah-perintah sesuai dengan keinginannya. Selama berabad-abad Iblis bersedia sujud di hadapan Allah, namun ia tidak mau bersujud sesaatpun kepada Adam.

2. Jauh dari keadilan, apabila semua malaikat bersujud kepada manusia, namun manusia tidak bersedia bersujud kepada Allah.

3. Sombong dan takabbur di hadapan kebenaran, menarik manusia kepada kekufuran dan ketidakberagamaan.

4. Sujud dan tunduk di hadapan selain Allah apabila berdasarkan perintah Allah, maka tidak hanya perbuatan non-syirik, bahkan ia merupakan tauhid dan ubudiyyah itu sendiri.

5. Kelayakan lebih penting dari pada umur dan keterdahuluan. Malaikat yang telah diciptakan terlebih dahulu harus bersujud kepada Adam yang baru diciptakan.

6. Sujud kepada Adam bukan hanya kepada dirinya, bahkan karena keturunannya dan generasi manusia. Oleh karenanya Allah berfirman dalam Surah al-A'raf ayat 11, 
"Wahai manusia, Kami ciptakan kalian, lalu kami bentukkalian, kemudiankami katakan kepada Malaikat: BersujudlahkepadaAdam!"

\section{Analisis Ayat Dengan Ayat Yang Lainnya}

Telaah ayat-ayat al-Quran yang berbicara tentang manusia, memberi gambaran kontradiktifmenyangkut keberadaannya. Disatu sisi manusia dalam al-Quran sering mendapat pujian Tuhan. Seperti pernyataan terciptanya manusia dalam bentuk dan keadaan yang sebaik-baiknya, kemudian penegasan tentang dimuliakannya makhluk ini dibanding dengan kebanyakan makhluk-makhluk lain. Sedang di sisi lain sering pula manusia mendapat celaan Tuhan. Seperti bahwa ia amat aniaya dan ingkar nikmat, dan sangat banyak membantah serta bersifat keluh kesah lagi kikir. Gambaran kontradiktif itu bukanlah berarti bahwa ayat-ayat yang berbicara perihal manusia bertentangan satu sama lain, melainkan justru menandakan bahwa makhluk yang bernama manusia itu unik, makhluk yang serba dimensi, dan makhluk yang berada di antara predisposisinegatif dan positif. Hal ini dapat difahami dengan mengkaji asal-usul kejadiannya, proses penciptaannya dan keragaman terminologinya dalam al-Quran.

Generasi manusia yang ada sampai sekarang, dalah berasal dari manusia pertama yang bernama Adam dengan istrinya yang populer bernama Hawa. Diantara ayat yang secara jelas menyatakan bahwa Adam dan Hawa adalah ayah dan ibu generasi manusia setelahnya, adalah:

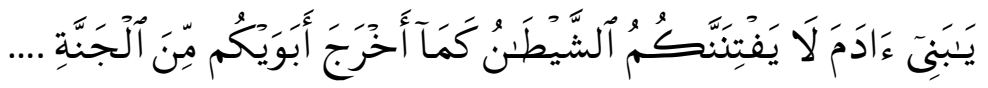

Artinya: "Hai anak-anak Adam,janganlah sekali-kalikamu dapatditipuolehsyetan, sebagaimana ia telah mengeluarkanibu-bapakmu dari surga...." (QS. Al-A'raf : 27)

Adam sendiri diciptakan dari tanah sebagaimana diceritakan oleh Allah SWT dalam beberapa firman-Nya yang salah satunya pada firman berikut:

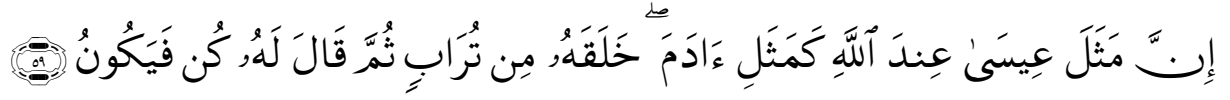

Artinya: "SesungguhnyaperumpamaanIsa di sisi Allah adalah semisalAdam. Allah menciptakanNya dari tanah, kemudianberfirmankepadanya,Jadilah' maka jadilah dia” (QS. Ali Imran: 59)

Ayat ini secara explisitmerupakan bantahan terhadap para pengagum Isa as yang menilainya sebagai anak Tuhan, karena beliau tidak lahir melalui seorang ayah, melainkan melalui kalimat Allah. Tetapi secara implisitmenjelaskan kejadian Isa as yang semisal dengan kejadian Adam as yaitu diciptakan dari tanah melalui proses yang mudah dan cepat sesuai dengan kehendak Allah SWT. Kata 'kun' pada ayat di atas tidaklah benar bila dijadikan dasar bahwa Adam as diciptakan dalam sekejap tanpa proses sebagaimana yang difahami kebanyakan 
orang. Karena disamping dalam hal mencipta Allah SWT, tidak memerlukan sesuatu apapun untuk mewujudkan apa yang dikehendaki-Nya, termasuk tidak perlu mengucapkan 'kun'. Juga karena pada ayat yang lain Allah SWT melukiskan, bahwa Dia menciptakan Adam as dari tanah, dan setelah Dia sempurnakan kejadiannya, Dia tiupkan ruh ciptaan-Nya.

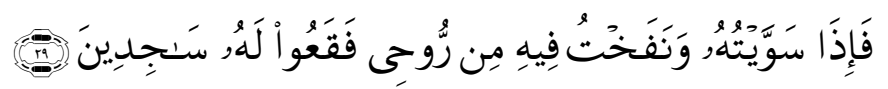

Artiinya: "Maka apabila Aku telahmenyempurnakankejadiannya (Adam), dan telah meniupkan ke dalamnya ruh (ciptaan)-Ku, maka tunduklah kamu kepadanyadenganbersujud"(QS. al-Hijr :29).

Selanjutnya kejadian generasi manusia setelah Adam as, penciptaannya diisyaratkan dalam ayat :

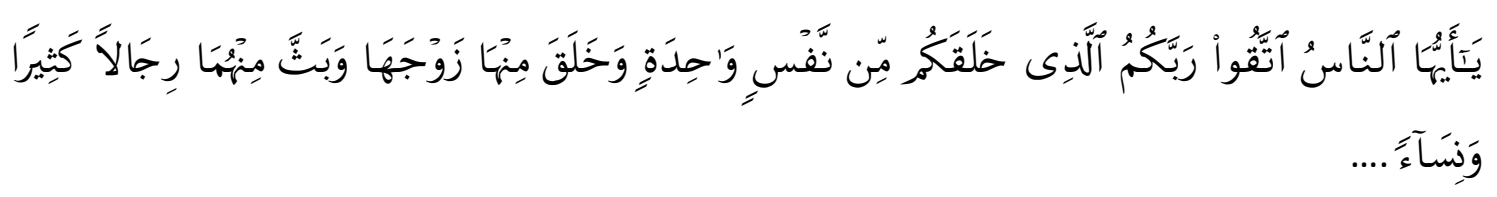

Artinya: "Hai sekalian manusia, bertakwalah kepada Tuhan kamu yang telah menciptakan kamu dari diri yang satu, dan menciptakandarinya pasangannya. Allah mengembangbiakkan dari keduanyalaki-laki yang banyak dan perempuan....'(QS. an-Nisa : 1)

Para Mufassir memahami kata 'nafsin wahidah' (diri yang satu) pada ayat ini dalam arti Adamas. Akan tetapi para Mufassir kontemporer seperti al-Qasimi, Syekh Muhammad Abduh memaknainya dalam arti jenis manusia lelaki dan wanita. Sehingga ayat ini kandungannya sama dengan firman Allah SWT :

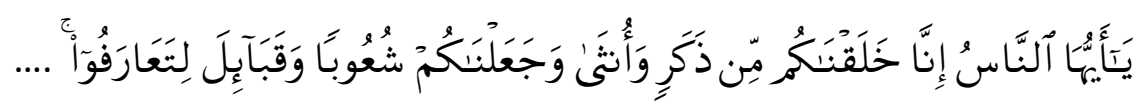

Artinya: "Hai sekalian manusia, sesungguhnyaKami telah menciptakankamu dari seorang laki-laki dan seorangperempuandan menjadikankamu berbangsa-bangsadan bersuku-suku supaya kamu saling mengenal"(QS. al-Hujurat : 13)

Maka kedua ayat di atas pada prinsipnya berbicara sama yaitu tentang asal kejadian manusia dari seorang ayah dan ibu, yakni spermaayah dan ovumibu. Hanya tekanannya saja yang berbeda. Jika ayat pertama dalam konteks menjelaskan banyak dan berkembang biaknya manusia dari seorang ayah dan ibu, maka ayat kedua konteksnya adalah persamaan hakikat kemanusian orang perorang, dimana setiap orang walau berbeda-beda ayah dan ibunya, tetapi unsur dan proses kejadian mereka sama. Sehingga tidak dibenarkan seseorang menghina atau merendahkan orang lain.

Dengan memaknai kata 'nafsin wahidah' dalam arti diri (jenis) yang satu, Thabathaba'i dalam tafsirnya menyatakan bahwa ayat tersebut juga memberi penegasan bahwa pasangan 
(isteri Adam) yang ditunjuk kata 'zaujaha' diciptakan dari jenis yang sama dengan Adam yakni dari tanah dan hembusan ruh Ilahi. Menurutnya sedikitpun ayat itu tidak mendukung faham yang beranggapan bahwa Hawa diciptakan dari tulang rusuk Adam sebagaimana yang difahami para Mufassir terdahulu.

Akan halnya hadis riwayat Abi Hazm dari Abi Hurairah ra yang kerap digunakan untuk memperkuat faham itu, selain tertolak kesahihannya sehingga tidak dapat digunakan hujjah (argumentasi), juga - sebagaimana mayoritas ulama kontemporer mengatakan - hadis tersebut tidaklah tepat jika difahami dalam pengertian harfiah, melainkan harus difahami dalam pengertian metafora. Maka konteksnya dalam rangka mengingatkan kepada kaum laki-laki agar menghadapi perempuan dengan bijaksana, mengingat ada sifat dan kodrat bawaan mereka yang berbeda. Tidak ada seorangpun yang mampu mengubah kodrat bawaan itu. Kalaupun ada yang berusaha, maka akibatnya akan fatal seperti upaya meluruskan tulang rusuk yang bengkok. ${ }^{10}$ Makhluk yang bernama manusia, dari mulai manusia pertama Adam as dan istrinya Hawa, juga Isa as, serta generasi manusia setelahnya berasal dari bahan baku yang sama yaitu dari unsur tanah dan hembusan ruh Ilahi. Hanya model penciptaannya saja yang berbeda. Penciptaan manusia sebagaimana disimpulkan Quraish Shihabterdiri dari empat model penciptaan. Model pertama menciptakan dengan tanpa ayah dan ibu, yaitu Adam as. Kedua menciptakan setelah disampingnya ada lelaki, yaitu isteri Adam as. Model ketiga menciptakan hanya dengan ibu tanpa ada ayah, yaitu Isa as. Dan yang terakhir menciptakan melalui pertemuan lelaki dan perempuan yaitu generasi manusia setelah Adam.

\section{E. Kesimpulan}

Manusia adalah makhluk ciptaan Tuhan yang paling unik dan paling sempurna di muka bumi ini, ini disebabkan manusia diberiakn Allah SWT berupa akal yang dapat membedakannya dengan makhluk-makhluq tuhan yang lainnya, dengan akalnya manusia bisa membedakan antara yang hak dan yang bathil, antara yang pantas dan tidak pantas di lakukan, bahkan seseorang yang tidak mempunyai pengetahuan hukum agama pun dengan bekal akal dan hati nuraninya bisa merasakan dan membedakan antara yang benar dan yang salah, karena tujuan penciptaan manusia memang untuk menjadi khalifah di muka bumi. Dalam Al-Quran konsep manusia terdiri dari beberap aspek yakni al-insan, al-basyar, an-nas, dan Bani Adam. Kata ini lazim diartikan sebagai manusia. Namun, jika ditinjau dari segi bahasa serta penjelasan quran itu sendiri, empat kata tersebut satu sama lain berbeda maknanya.

\footnotetext{
${ }^{10}$ Muhammad Quraish Shihab, Tafsir Al Misbah (Jakarta, Lentera Hati : 2000, Vol. 2), h. 102
} 


\section{DAFTAR PUSTAKA}

Hasan Langgulung, Manusia Dan Pendidikan, Jakarta: Pustaka al-Husna, 1984.

Muhammad Fu'ad Abdul Baqi, Al-Mu'jam al-Mufahras li alfadz al-Qur'an al-Karim, T.kp.: Darul Fikri , 1992.

M.Quraish Shihab, Wawasan al Qur'an, Bandung : Penerbit Mizan, Cetakan VII, April 1998), h. 284

M. Quraish Shihab, Wawasan al-Qur'an; Tafsir Maudhu'i atas Pelbagai Persoalan Umat, Bandung : Mizan, 1996.

Muhammad Quraish Shihab, Tafsir Al Misbah (Jakarta, Lentera Hati : 2000, Vol. 2

Rif'at Syauqi Nawawi, Konsep Manusia Menurut al-Qur'an, Makalah Disampaikan Pada Simposium Psikologi Islami, Pada Sabtu, tanggal, 14 Desember 1996, Universitas Padjadjaran, Bandung, 1996.

Samsul Nizar, M.A., Filsafat Pendidikan Islam, Pendekatan Historis, Teoritis dan Praktis, Jakarta: Ciputat Pers, 2002.

Syaikh Imam Al Qurthubi, Tafsir Al Qurthubi, Jakarta:Pustaka Azzam, 2009.

Usman, M Ali, Manusia Menurut Islam, Bandung: Mawar, 1970. 